\title{
Correction to: Therapeutic hypernatremia management during continuous renal replacement therapy with elevated intracranial pressures and respiratory failure
}

\author{
Tibor Fülöp ${ }^{1,2}$ • Lajos Zsom ${ }^{3} \cdot$ Rafael D. Rodríguez ${ }^{1}$ • Jorge O. Chabrier-Rosello ${ }^{1}$ Mehrdad Hamrahian ${ }^{4}$. \\ Christian A. Koch ${ }^{5,6,7,8}$
}

Published online: 6 May 2019

(C) Springer Science+Business Media, LLC, part of Springer Nature 2019

\section{Correction to: Reviews in Endocrine and Metabolic Disorders https://doi.org/10.1007/s11154-019-09483-2}

The authors would like to report an error in the formula describing the correction factor for the protein content in the serum/plasma. The formula is described as "multiply by $(1-($ serum protein content, in $\mathrm{g} / \mathrm{L})]$ and is currently written on the 5th page of the article, right column text; moreover, on page 6, under Table 3 - Legend.

The corrected formula should be written as "multiply by $(1-(\text { serum protein content, in } \mathrm{g} / \mathrm{mL})]^{\prime \prime}$.

Publisher's note Springer Nature remains neutral with regard to jurisdictional claims in published maps and institutional affiliations.

The online version of the original article can be found at https://oi.org/ 10.1007/s11154-019-09483-2

\footnotetext{
Tibor Fülöp

tiborfulop.nephro@gmail.com

$\bowtie$ Christian A. Koch

Christian.koch65@gmail.com

1 Department of Medicine - Division of Nephrology, Medical

University of South Carolina, Charleston, SC, USA

2 Medical Services, Ralph H. Johnson VA Medical Center, Charleston, SC, USA

3 Fresenius Medical Care Hungary Kft, Cegléd, Hungary

4 Department of Medicine - Division of Nephrology, Thomas Jefferson University, Philadelphia, PA, USA

5 Medicover $\mathrm{GmbH}$, Berlin, Germany

6 Carl von Ossietzky University of Oldenburg, Oldenburg, Germany

7 Technical University of Dresden, Dresden, Germany

8 University of Tennessee Health Science Center, Memphis, TN, USA
} 